This document conslets of 8 posen

Septenber O, 1900

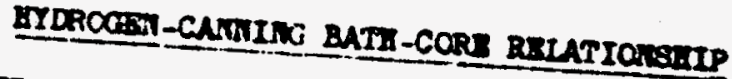

\section{CONY IINGRe}

1
2
3
4
-5

\section{DISCLAIMER}

This report was prepared as an account of work sponsored by an agency of the United States Government. Neither the United States Government nor any agency thereof, nor any of their employees, makes any warranty, express or implied, or assumes any legal liability or responsibility for the accuracy, completeness, or usefulness of any information, apparatus, product, or process disclosed, or represents that its use would not infringe privately owned rights. Reference herein to any specific commercial product, process, or service by trade name, trademark, manufacturer, or otherwise does not necessarily constitute or imply its endorsement, recommendation, or favoring by the United States Government or any agency thereof. The views and opinions of authors expressed herein do not necessarily state or reflect those of the United States Government or any agency thereof.

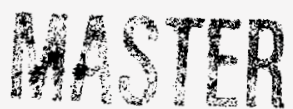

BEST WOY AVALAELE

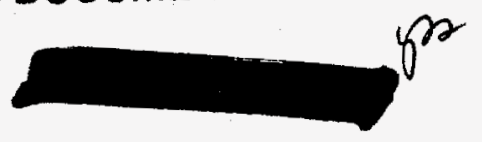




\section{DISCLAIMER}

Portions of this document may be illegible in electronic image products. Images are produced from the best available original document. 
The duylax Al-31 is; percent 81 and the enning beth is 11.2 parcent 81 . The duplax and cannina betb N-51 temperreture 18 soout 609 and $388 \mathrm{C}$, respectively. Thus, using 11 gure 1 and the cbove equation, the equll1. trium relu at one atmoephere $\mathrm{A}_{2}$ preseure for the duplex end ceaning bethe is 0.232 and 0.237 ce $\mathrm{H}_{2}$ (SIP) / $100 \mathrm{er} \mathrm{Al}-\mathrm{B1}$, respoct 1 vely.

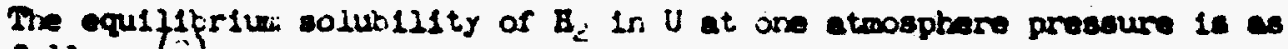
rollow: $\left(\begin{array}{l}(\vdots 2 \\ \vdots\end{array}\right.$

$\frac{\text { Turpersture } c}{002}$

ㅌ.2, pre
2.2
2.0
2.8
1.6

2r.18 relationst:1p is plotted in Plowe ì.

Assumiry, 1) Blevart's lav Is obeyed, i) that the dseolved Bz in the Al-S1

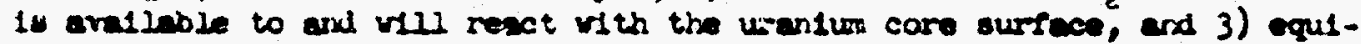

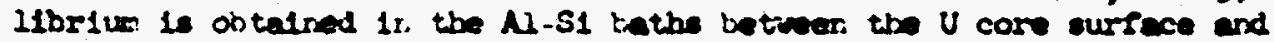
diseolved $a_{2}$ I: the Al-S1; a relationahip exists between tho duplex and cenning beth Al-SI and $\mathrm{H}_{2}$ cortent or tre core surfece as show in Figuro 3 .

The range of 4 , concentration foust in our $\mathbf{M - 3 1}$ beth during operation is

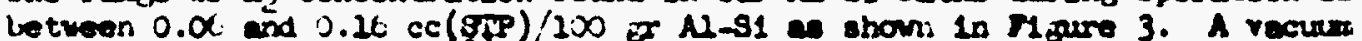
colldiflestion tochalque $(3)$ is uned for woseuring the $B_{2}$ content in the 1-81. Thus, to be below the range of $\mathrm{B}_{2}$ found in the Al-81 bethe, whe core surface th wint be belor 0.4 pga.

It 1s doubtrul that equllibrium vould be obtalned in the onneng operation ince the cares are in contact 1 th molten A1-81 for a vary abort time;

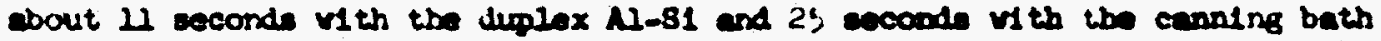
11-81. While the core is belag prohented, wheh takes 30 cooonds to reach bath tempereture at the midds of the tubenull, the care is aubrexped in a andten leed laver belov the M1-81 far 34 secords.

(द) M. H. Mallett and H. J. Irsecik, "Butrogen-U Ralationsh1p", Trensections of the A.S.M., Yal. 50, p. 985,1958 .

(3) A "Bpoedy Co Detector" is unad mich is apurectured hy the Marry W. DLetort Compan, 9330 Boselesis Av., Detrost 4, Mahtons. 


\section{GENEAAL GT ELETRIC}

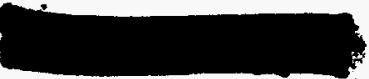

X. I. Devmenn
$-14-66737$

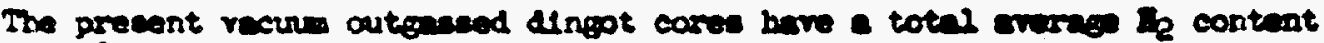

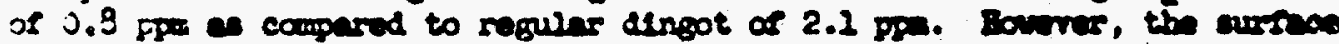
$B_{2}$ on the prowent recurm outgasend cares wist be blop eloce our breze

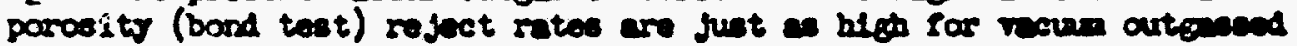

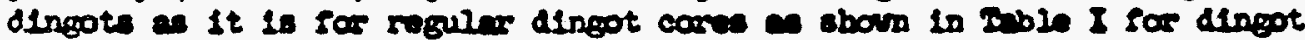

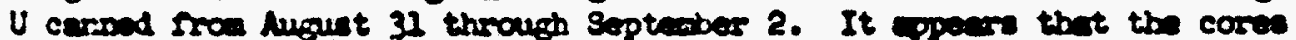
vere respaneible for wost of the bond rejects, sines the reoovered linept Lot had carelderibly leas band rejecte. The bond re ject rate for tro Ineot core lots canned funt prior to the dineot 20 ts 10 elso iscluded in Tutle I for couparison.

W ere hoparul that recurum outgaseing after or during bote beat treating

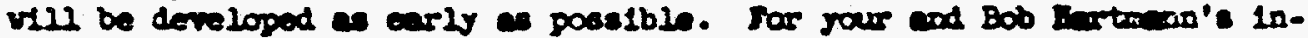

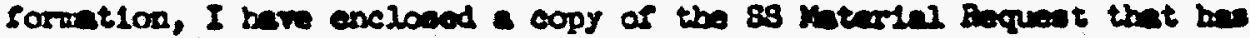

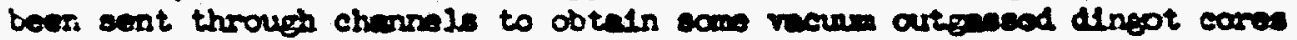
outgases in finel core form after beat treating.

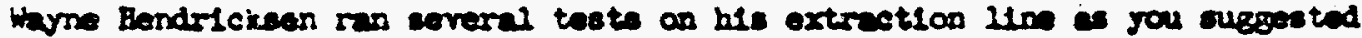
and found that the mextrus proseure be could obtale vefore becketrening

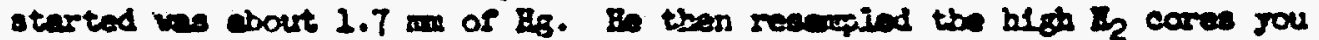

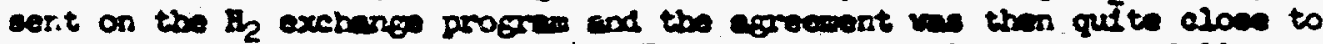

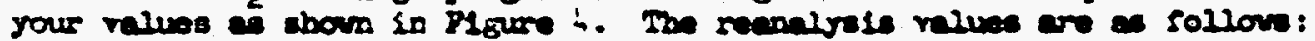

$\cos$ number
$40,211-21$
$405842-20$
$415413-20$
$4062122-24$

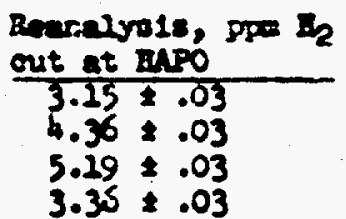

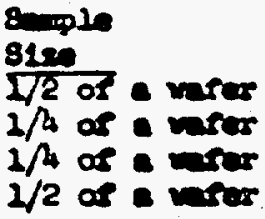

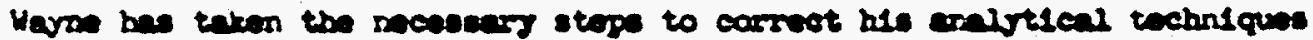

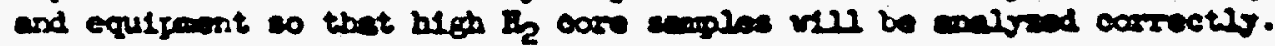

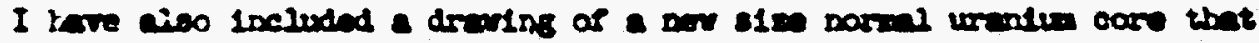
Bob Bartmens vill wat for bis f12s.

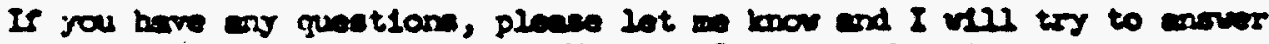

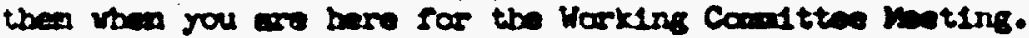

Yors towy yours, 


\section{GENEAAL ELEGTAIC}

Dar I

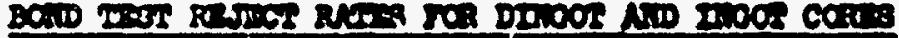

Irants

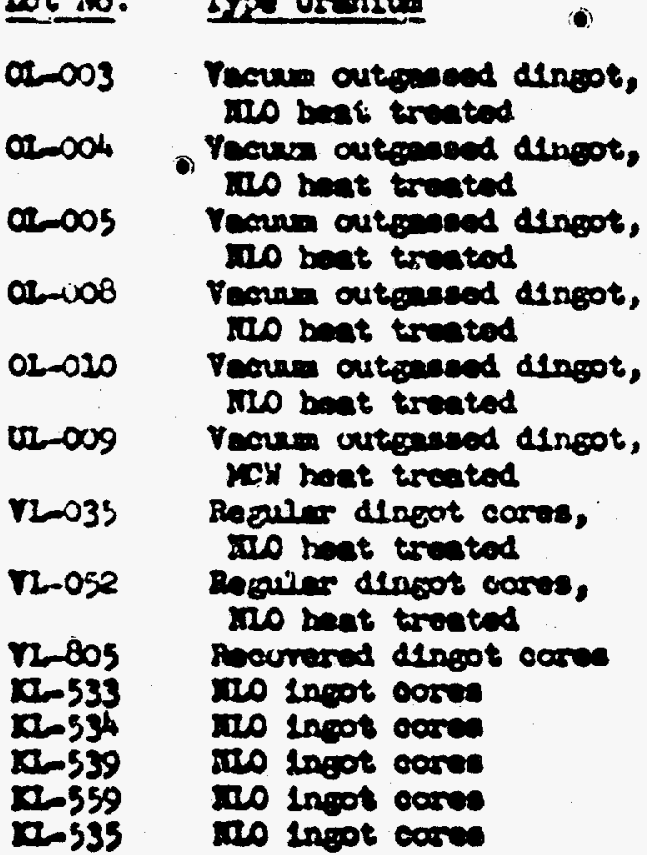

9

10. Connad

4664

3321

4778

2422

4623

586

3576

2942

2403

6300

4028

1327

4059

3012
4 Bond 200t

Doseotes

5.58

4.2

6.6

9.4

5.9

4.4

6.5

4.7

2.7

2.6

2.5

3.2

2.4

3.2
Conniog

(9) Date

8-32

8-31

$9-1$

9-2

9-1

9-2

9-2

8-31

8. 32

$8-29$

$8-89$

$8-29$

8. 30

Q-30

O 


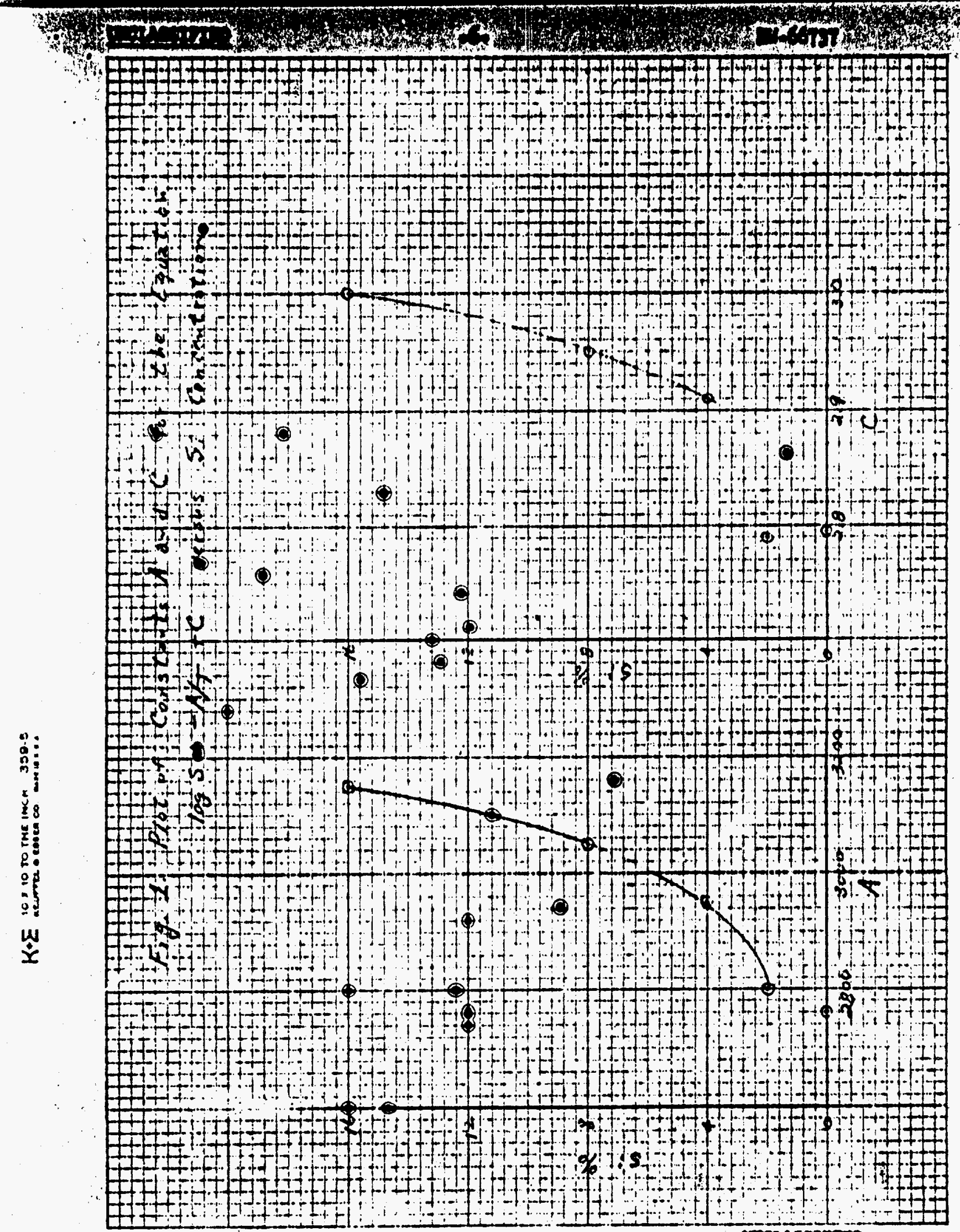

yosenesos 


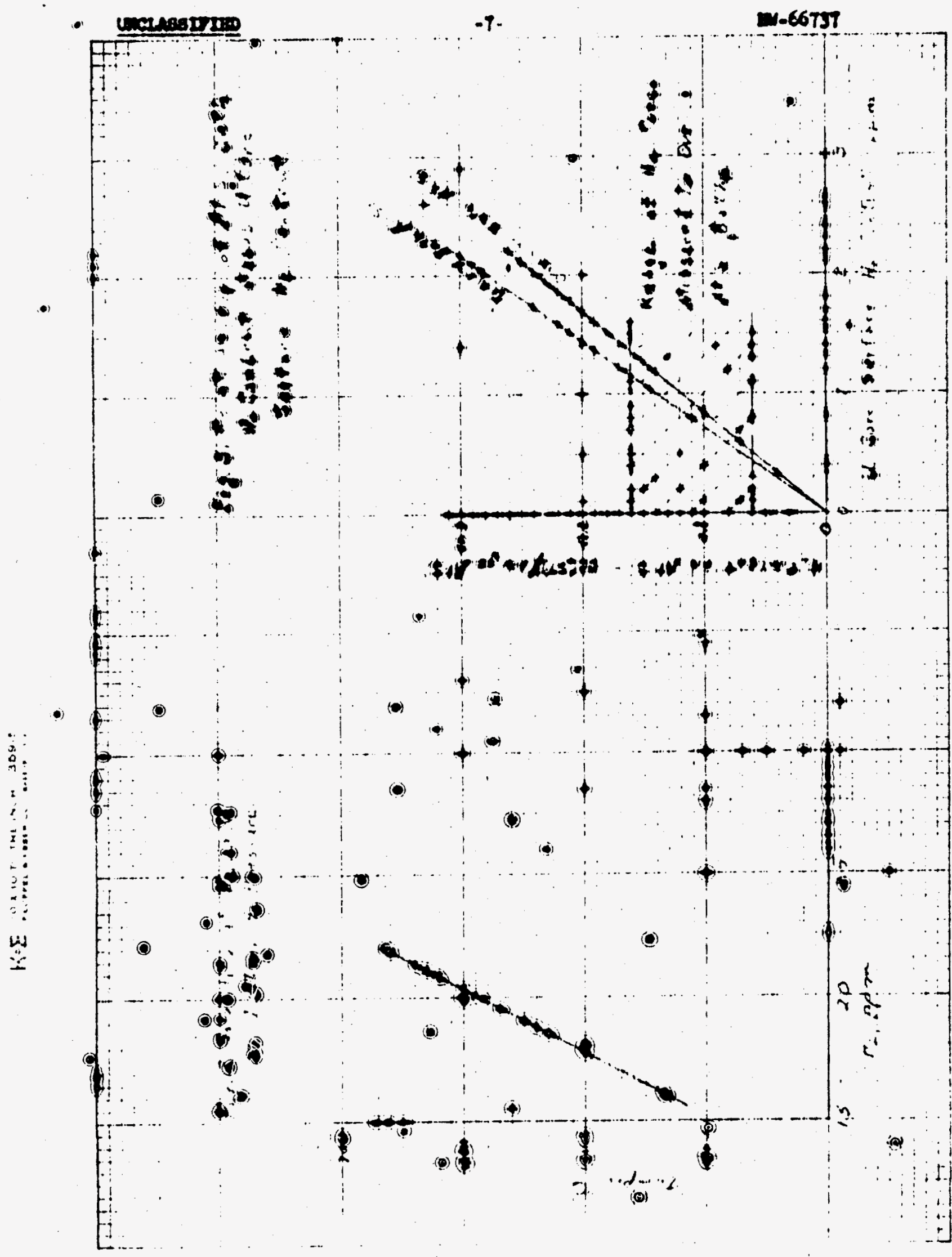


